\title{
MANAGEMENT INFORMATION SYSTEM IN EVALUATION OF BCA MOBILE BANKING USING DELONE AND MCLEAN MODEL
}

\author{
Astri Ayu Purwati ${ }^{*}$, Zainol Mustafa ${ }^{2}$, Mazzlida Mat Deli ${ }^{3}$ \\ Department of Management, Institut Bisnis dan Teknologi Pelita Indonesia ${ }^{1}$ \\ School of Mathematical Sciences, Universiti Kebangsaan Malaysia ${ }^{2}$ \\ Faculty of Education, University Kebangsaan Malaysia ${ }^{3}$ \\ astri.ayu@ lecturer.pelitaindonesia.ac.id ${ }^{1}$
}

Received : 11 April 2021, Revised: 9 May 2021, Accepted : 9 May 2021

*Coresponding Author

\begin{abstract}
The investment in information system brings significant impacts on the banking industry because it plays a pivotal role in providing better services and competitive edges. This study evaluated satisfaction level and benefit of the usage of the banking system which is m-Banking using the IS Success Model approach developed by DeLone and McLane in 2003. The population in this study was customers of one of the largest banks in Indonesia, namely Bank Central Asia (BCA) with a sample size of 200 customers. The data were analyzed using Structural Equation Model (SEM) with AMOS. The results showed that the IS Success Model consisting of system quality, information quality and service quality has a significant impact on customer satisfaction in using BCA m-Banking. This study also validates the research conducted by DeLone and McLean (2003) in developing the IS Success Model as a measure of the quality and key to the success of an information system.
\end{abstract}

Keywords : IS Success Model; Mobile Banking; DeLone and McLean

\section{Introduction}

Over the past few years, information technology has advanced rapidly and significant from year to year. Information technology users enjoy a lot of convenience due to it. Mobile banking is a facility from a bank in this modern era that follows developments in technology and communications. The services contained in mobile banking include payments, transfers, history, and so on. The use of mobile banking ser-vices on cellphones enable customers to execute their banking activities with ease anytime and anywhere. It is expected to provide ease and benefits to customers in accessing the bank without having to be physically present in the place. Banking service through mobile banking has been consistently offered through electronic media or during the application for a new bank account. The low rate of adoption may be due to several factors such as lack of knowledge of the convenience and benefits of mobile banking services as well as preferences to use manual transactions by coming directly to the bank to queue.

The investment in information system brings significant impacts on the banking industry because it plays a pivotal role in providing better services and competitive edges. This represents a challenge for organizations to continue to improve the performance of information systems in banking(Al-Ghazali, et. al., 2015).

A system is a unit composed of a number of elements. Based on that definition, it can be concluded that the system is a collection of elements whose functions are interconnected and organized, into a unit that has a function of creating balance and efficiency in a work. Evaluation of information system is necessary to determine the quality of the use of the system. In evaluating information system, several success models have been developed by researchers (Jeong, H. Y., \& Kim, Y. H., 2012; Yakubu, M. N., \& Dasuki, S., 2018; Booth, 2012). DeLone and McLean's 1992 model received much attention from subsequent researchers(Jeong, H. Y., \& Kim, Y. H., 2012; Hsu, et. al., 2014; Tona, et. al., 2012). In 2003, De-Lone and McLean revised their model and it received similar attention as the first iteration. One reason is that their model is a simple one but reliably valid(Al-Debei, et. al., 2013).

A number of studies also showed several aspects in evaluating information system, such as information user satisfaction, system usage and information value. Some researchers propose 
to use user satisfaction as a measure of information system use(Sharkey, et. al., 2010). System quality and information quality are significant predictors of user satisfaction and intended use. User satisfaction is a significant predictor for intended use and individual impact. Intended use is also a significant predictor of user satisfaction and individual impact. Lastly, individual impact affects organizational performance (organizational impact).

\section{Literature Review \\ System quality on system usage satisfaction}

The model developed by DeLone and McLean in 2003 is a model that reflects the dependence of six measures of information success. Many studies were conducted to examine the effect of system quality on user satisfaction in the study. Previous studies have shown positive results of the effect of information system quality on user satisfaction(Shim, M., \& Jo, H. S., 2020). When a system is perceived as a quality system, the users are likely to be satisfied in using the system. Information system users who get the de-sired results from a system will feel more satisfied and be more likely to continue to use the system. Based on this argument, the following hypothesis was formulated:

Hypothesis 1: System quality has a positive effect on m-banking user satisfaction

\section{System quality on user satisfaction}

Information quality dimension is the key factor of an end user satisfaction instrument(Alzahrani, et. al., 2020). As a result, information quality is often not used as a unique idea but is measured as a component of user satisfaction. DeLone and McLane stated that information quality can affect system user satisfaction. In contrast, the results of previous studies indicated that quality of information does not affect user satisfaction(Halim, et. al., 2016; Sarkheyli \& Song, 2018). If an information system can provide quality information, a user will be more likely to be more satisfied with the information obtained. Based on this argument, the following hypothesis was formulated:

Hypothesis 2: Information quality has a positive effect on m-banking user satisfaction

\section{Service quality on user satisfaction}

Service quality is defined as an assessment perceived by comparing user expecta-tions with the level of perception received by customers about the service they receive(Riasti \& Nugroho, 2019; Fang, et. al., 2011). Previous studies showed that service quality affected user satisfaction, similar to system and information quality(Riasti \& Nugroho, 2019). Improving the quality of information system services will give satisfaction to users if user expectations and perceptions received are compatible in which service quality provides user satisfaction. Based on this argument, the following hypothesis was formulated:

Hypothesis 3: Service quality has a positive effect on m-banking user satisfaction

\section{User satisfaction on net benefits}

Net benefits are commonly measured in organization performance. Perceived benefits are the effect of using information systems. The relationship between system end user satisfaction and net benefits has been investigated in several previous studies(Fang, et. al., 2011; Al-Debei, 2014). When users are satisfied with the service they use, they are more likely to feel secure and convenient in using it. It is argued that the higher the user satisfaction of an information system, the greater the net benefits will be for users. Based on this argument, the following hypothesis was formulated:

Hypothesis 4: User satisfaction has a positive effect on net benefits

Based on the background above, the framework for the IS Success Model in using mobile banking is as follows: 


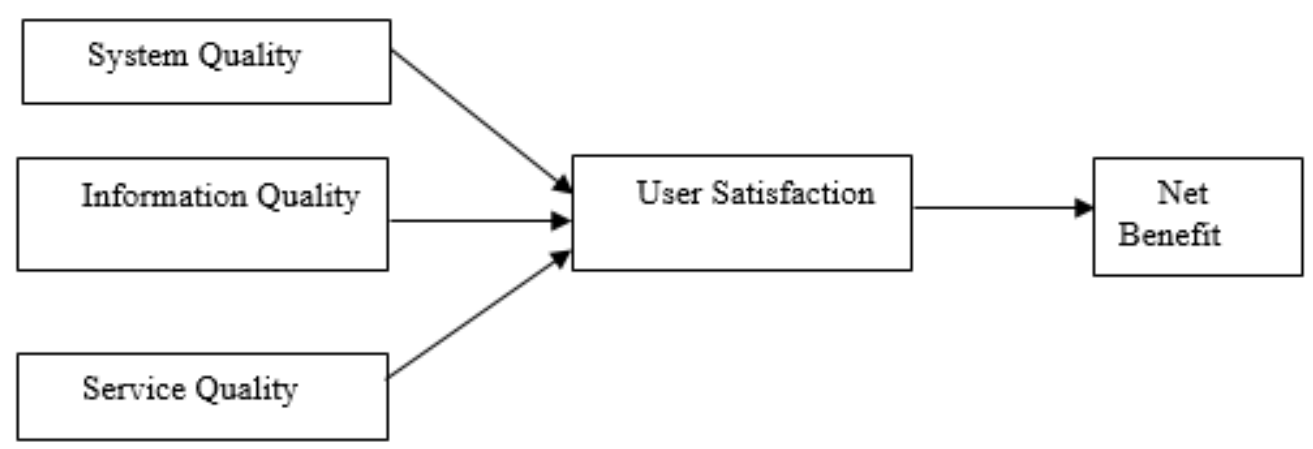

Fig. 1. Research Framework

\section{Research Methods}

\section{Population and Sample}

The population in this study was customers of one of the largest banks in Indonesia, namely Bank Central Asia (BCA) in Pekanbaru, Riau Provice with a sample size of 200 customers. The optimal number of samples was 100-200 respondents.

\section{Study Instrument Design}

The instrument in this study was a questionnaire. There were 2 ways of conducting a study with questionnaire as the instrument, namely by personally administering questionnaires to groups of individuals and by mail questionnaires. Measurement of the questionnaire was performed using 5-point Likert scale. Respondents were asked questions about how much they thought about these questions using a Likert scale of 1-5, where scale 1 represented "strongly disagree" and scale 5 represented "strongly agree", as in the following model:

\begin{tabular}{llllc} 
Strongly disagree & & & Strongly Agree \\
\hline 1 & 2 & 3 & 4 & 5
\end{tabular}

Operational Definition of Variables

Table 1 - Operational Definition of Variables

\begin{tabular}{ll}
\hline Variable & Attribute/Indicator \\
\hline System Quality & Functionality \\
& Reliability \\
& Utility \\
& Accessibility \\
\hline Information Quality & Accuracy \\
& Timeliness \\
& Relevance \\
& Precision \\
& Informativeness \\
\hline Service Quality & Reliability \\
& Service \\
& Response \\
& Guarantee \\
& Empathy \\
\hline User Satisfaction & Product stability \\
& Familiarity in using a product \\
& Product recommendation \\
& Ease of use of the product \\
& Meeting expectation \\
\hline Net Benefit & Trust \\
& Emotion commitment \\
& Switching cost \\
& Word of mouth \\
& Cooperation \\
\hline
\end{tabular}




\section{Structural Equation Modeling Analysis}

Theoretical review was used to develop the base model for subsequent steps. The constructs and dimensions to be studied from the theoretical model have been developed in theoretical studies and hypothesis development. This study used the multivariate Structural Equation Model (SEM) technique, on the ground that SEM had the ability to combine measurement models and structural models simultaneously when compared to other multivariate techniques. In addition, the SEM technique enabled us to test the direct and indirect effect. The software used for data processing using SEM was AMOS 4.

\section{Results and Discussions}

Bank Central Asia (BCA) Mobile Banking Application

Below are the features of Bank Central Asia Mobile Banking:

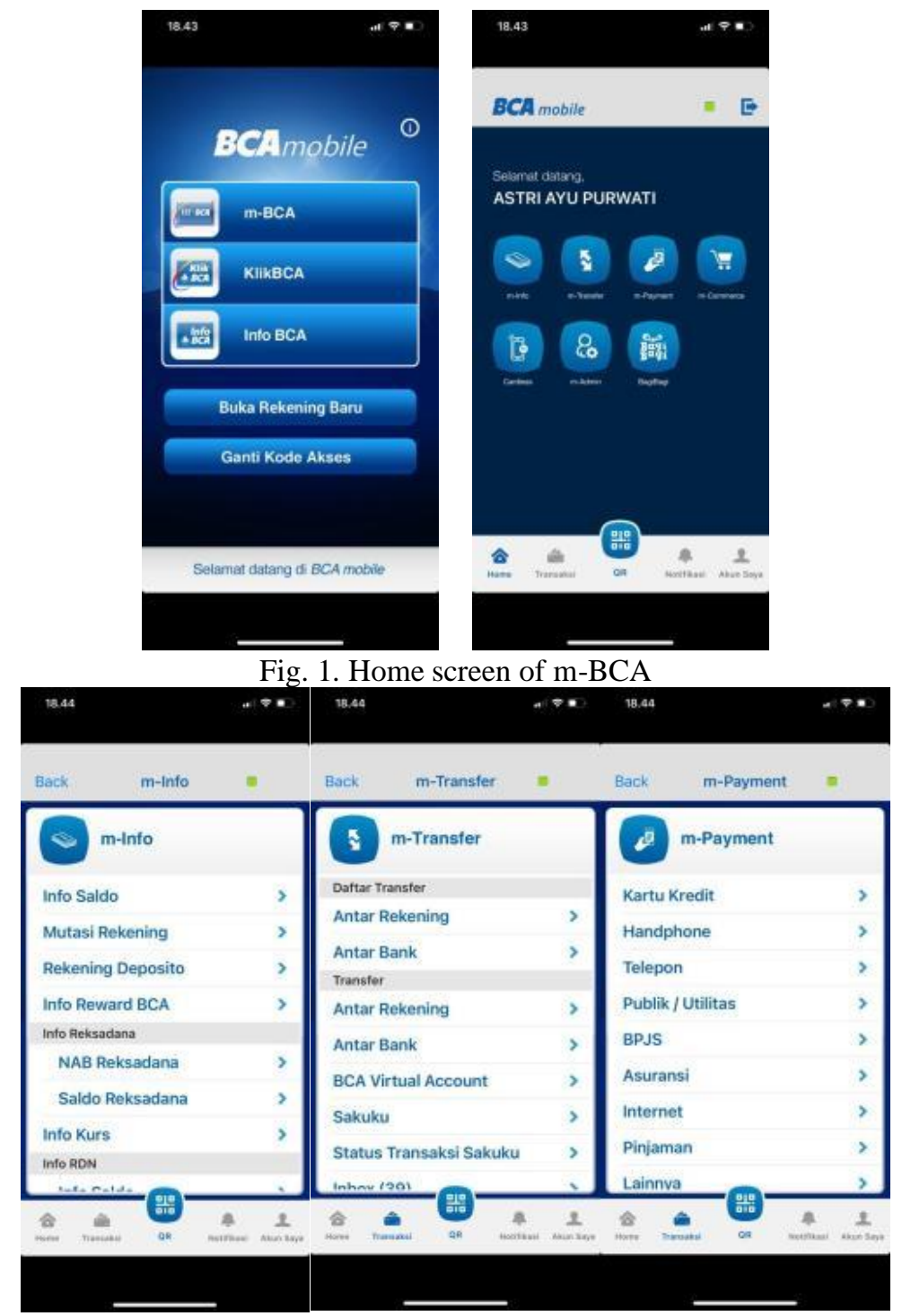




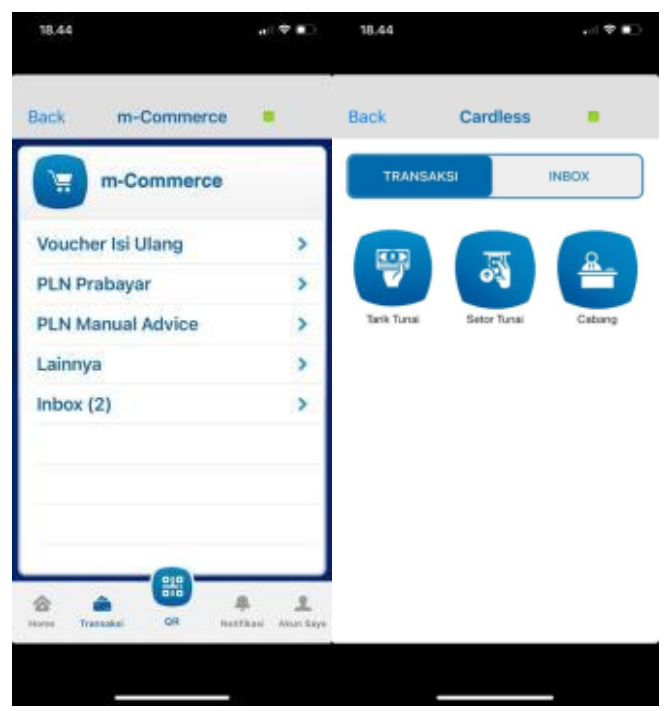

Fig. 2. Feature screen of m-BCA

Figure 1 and 2 above showed the home screen and features offered by m-BCA to its customers/users. The features include:

1) m-Info, which provides customer with financial information such as balance information, account mutations, deposit accounts, rewards, etc.

2) m-Transfer, which functions to assist customers in making fund transfers both to fellow BCA banks and between banks. m-Transfer is also equipped with transfer features via BCA Virtual Account and Sakuku.

3) m-Payment, which functions to help customers make payments such as credit cards, postpaid mobile phones, telephone, utilities, insurance, Internet, loans, etc.

4) Cardless is a feature that functions as a substitute for an ATM card when a customer wants to make cash withdrawals or cash deposits to an ATM.

Analysis of the Usability of BCA Mobile Banking Application using the IS Success Model Model Feasibility Test

Until determining the viability of a structural model, the step that must be taken is to determine whether the data to be processed satisfies the assumptions of the structural equation model. Assessing the goodness-of-fit is the main goal of SEM to find out how far the hypothesized model is "fit" or fits the data sample. The results of goodness-of-fit are shown in the following table:

Table 2 - Goodness of Fit Result

\begin{tabular}{lccc}
\hline $\begin{array}{c}\text { Goodness of } \\
\text { Fit Index }\end{array}$ & Cut-off* & Results & Conclusion \\
\hline Chi-Square & & 613.094 & \\
\hline Probability & $\geq 0.05$ & 0.000 & Marginal \\
\hline G F I & $\geq 0.90$ & 0.857 & Marginal \\
\hline A G F I & $\geq 0.90$ & 0.821 & Marginal \\
\hline T L I & $\geq 0.90$ & 0.911 & Fit \\
\hline C F I & $\geq 0.90$ & 0.923 & Fit \\
\hline N F I & $\geq 0.90$ & 0.851 & Marginal \\
\hline I F I & $\geq 0.90$ & 0.924 & Fit \\
\hline RMSEA & $0.05-0.08$ & 0.059 & Fit
\end{tabular}

Source: Processed Data (2020).

Based on the results in the table above, it can be seen that the research model was close to a fit model. It is shown by the TLI $(0,911)$, CFI $(0,923)$, IFI $(0,924)$ and RSMEA $(0,059)$ values whose models have met the fit criteria while Probability $(0,000)$, GFO $(0,857)$, AGFI $(0,821)$ and 
NFI $(0,851)$ were close or marginal. It means that through testing, the model is declared fit and eligible for the next tests.

Hypothesis Test for Path Analysis with Analysis of Moment Structure (AMOS) Table 2 - Hypothesis Test for Path Analysis

\begin{tabular}{|c|c|c|c|c|c|}
\hline & Exogenous Variable & $\begin{array}{l}\text { Endogenous } \\
\text { Variable }\end{array}$ & $\begin{array}{l}\text { Standardized } \\
\text { Coefficient }\end{array}$ & $\begin{array}{c}\text { Critical } \\
\text { Ratio }\end{array}$ & p-value \\
\hline $\mathrm{H}_{1}$ & System Quality $\left(X_{1}\right)$ & $\begin{array}{c}\text { User } \\
\text { Satisfaction }\left(Y_{1}\right)\end{array}$ & 0.103 & 0.920 & 0.000 \\
\hline $\mathrm{H}_{2}$ & Information Quality $\left(X_{2}\right)$ & $\begin{array}{c}\text { User } \\
\text { Satisfaction }\left(Y_{1}\right)\end{array}$ & 0.942 & 6.244 & 0.000 \\
\hline $\mathrm{H}_{2}$ & Service Quality $\left(X_{3}\right)$ & $\begin{array}{c}\text { User } \\
\text { Satisfaction }\left(Y_{1}\right)\end{array}$ & 0.009 & 0.082 & 0.005 \\
\hline $\mathrm{H}_{4}$ & User Satisfaction $\left(Y_{l}\right)$ & Net Benefit $\left(Y_{2}\right)$ & 0.005 & 0.021 & 0.028 \\
\hline
\end{tabular}

Source: Processed Data (2020).

\section{Effect of System Quality on User Satisfaction}

Based on the analysis on hypothesis 1, it was known that system quality had a significant effect on user satisfaction, in this case is students. It means that the better the information system quality offered in BCA m-Banking, the higher the customer satisfaction in using m-banking. The standard of the system consists of adaptability, accessibility, reliability, time of response and usability. Adaptability is the ability to adapt to a system's ability (e.g. a computer system) to adapt to various circumstances effectively and quickly. Therefore, adaptive systems are open systems that are able to adjust behavior according to changing environments or from the system itself. In testing and maintenance, availability refers to the existence of a reliable device. It is typically quicker and more accurate to improve maintenance and upkeep. Reliability implies the capacity of a device or component to operate for a given period of time under stated conditions. Answer time is the cumulative amount of time it takes to answer a request for a specific service again. Usability is the ease of operation and learning of university information systems in order to communicate effectively (Shim, M., \& Jo, H. S., 2020). In this regard, the quality of the BCA mbanking system which consists of functionality, reliability of the system provided, level of usability and accessibility is good and is considered capable of providing user (Tam \& Oliveira, 2017). Today's users need a system that is reliable and able to meet their transaction needs more efficiently than physically coming to an ATM or a bank.

\section{Effect of Information Quality on User Satisfaction}

The analysis on hypothesis 2 showed that information quality had a significant effect on $\mathrm{m}$-baking user satisfaction. The higher the information quality of BCA m-Banking, the more likely it is for users to feel satisfied and loyal. The quality information of m-Banking is measured by the accuracy of the information provided. In addition to transactional features, the service also provides information on the use of each of these features and all updated information related to BCA bank and the products offered(Sarkheyli, A., \& Song, W. W., 2018). Furthermore, the timeliness and relevance of the information provided on m-Banking are also important things that $\mathrm{m}$-Banking users expected. Precision and informativeness are also considered good because the information features provided by m-BCA are very informative. The results were in line with previous studies demonstrating that system quality had a dominant effect on user satisfaction.

\section{Effect of Service Quality on User Satisfaction}

The analysis on hypothesis 3 showed that service quality had a significant effect on mbaking user satisfaction. Improving the quality of banking services, especially in the m-Banking system, is very necessary considering customers choose a bank that provides good and efficient service quality and brings high satisfaction to users(Mansour, 2020).

Service quality of an m-Banking which consists of reliability, service. Response, Assurance and Empathy must be able to support a system that is more efficient than the services provided by humans. In this case, the completeness of elements of banking services provided by $\mathrm{m}$-Banking BCA has been able to bring satisfaction to users. This is in line with the study by previous research showing that good service quality of a system will be able to increase user satisfaction(Mobaseri, et. al., 2014). 


\section{Effect of User Satisfaction on Net Benefits}

Net benefits are effects arising from the use of information systems on individuals, groups, organizations, industry, society, etc. Organizational aspects can be measured from organizational performance, perceived usefulness, and influence on work practice. If someone is satisfied with the information system used, they will tend to feel safe and comfortable using the information system. The results of analysis on hypothesis 5 indicate that user satisfaction has an effect on the net benefits obtained due to the use of m-Banking. This shows that there are many conveniences obtained by BCA m-Banking users. It is known that BCA is a bank in Indonesia that has a quality information system and $\mathrm{m}$-Banking, thus the quality of $\mathrm{m}$-Banking provided is able to meet the needs of its customers. The results of this study are in line with previous studies where user satisfaction has an effect on net benefit(Klobas \& McGill, 2010). The higher the user satisfaction shows the better aspects of the benefits of a system

\section{Conclusion}

The conclusion drawn from this study is that the information system quality of $m$-Banking BCA using the IS Success Model is pretty good where the service features provided by the $\mathrm{m}$ Banking system are able to give satisfaction to its users. It includes benefits in meeting user transactional need since users no longer have to be physically present in the bank or ATM to conduct certain forms of transaction. The results of this study are also expected to provide feedback to the Bank BCA to improve the BCA m-Banking information system in a better direction because the use of $\mathrm{m}-\mathrm{BCA}$ itself has been welcomed and provides enormous benefits to user custom-ers. It also validates the study by DeLone and McLone in developing the IS Success Model as the instrument to measure quality and success factors of an information system.

\section{References}

Alzahrani, A. I., Mahmud, I., Ramayah, T., Alfarraj, O., \& Alalwan, N. (2019). Modelling digital library success using the DeLone and McLean information system success model. Journal of Librarianship and Information Science, 51(2), 291-306.

Al-Debei, M. M. (2014). The quality and acceptance of websites: an empirical investigation in the context of higher education. International Journal of Business Information Systems, 15(2), 170-188.

Al-Debei, M. M., Jalal, D., \& Al-Lozi, E. (2013). Measuring web portals success: a respecification and validation of the DeLone and McLean information systems success model. International Journal of Business Information Systems, 14(1), 96-133.

Al-Ghazali, B. M., Rasli, A. M., Yusoff, R. M., \& Mutahar, A. Y. (2015). Antecedents of continuous usage intention of mobile banking services from the perspective of DeLone and McLean model of IS success. International Journal of Economics and Financial Issues, $5(1 S)$.

Booth, R. G. (2012). Examining the functionality of the DeLone and McLean information system success model as a framework for synthesis in nursing information and communication technology research. CIN: Computers, Informatics, Nursing, 30(6), 330-345.

Fang, Y. H., Chiu, C. M., \& Wang, E. T. (2011). Understanding customers' satisfaction and repurchase intentions: An integration of IS success model, trust, and justice. Internet research.

Halim, E., Setiawan, D. P., \& Novela, E. S. (2016, November). Factors affect quality of SMEs' online marketing website based on DeLone and McLean Model. In 2016 International Conference on Information Management and Technology (ICIMTech) (pp. 338-343). IEEE.

Hsu, M. H., Chang, C. M., Chu, K. K., \& Lee, Y. J. (2014). Determinants of repurchase intention in online group-buying: The perspectives of DeLone \& McLean IS success model and trust. Computers in Human Behavior, 36, 234-245.

Jeong, H. Y., \& Kim, Y. H. (2012). A system software quality model using DeLone \& McLean model and ISO/IEC 9126. International Journal of Digital Content Technology and its Applications, 6(5), 181-188. 
Klobas, J. E., \& McGill, T. J. (2010). The role of involvement in learning management system success. Journal of Computing in Higher Education, 22(2), 114-134.

Mansour, M. M. O. (2020). Acceptance of mobile banking in Islamic banks: integration of DeLone and McLean IS model and unified theory of acceptance and use of technology. International Journal of Business Excellence, 21(4), 564-584.

Mobasheri, M., Saghaeiannejad-Isfahani, S., Saeedbakhsh, S., Jahanbakhsh, M., Khaledifar, B., \& Habibi, M. (2014). An assessment and comparison of information quality of hospital information systems in medical-teaching hospitals of the city of Isfahan based on delone and McLean's modified model. Life Science Journal, 11(9), 425-431.

Riasti, B. K., \& Nugroho, A. (2019, December). Analysis of the success of student monitoring information system implementation using DeLone and McLean model. In Journal of Physics: Conference Series (Vol. 1339, No. 1, p. 012063). IOP Publishing.

Sarkheyli, A., \& Song, W. W. (2018, November). Delone and McLean IS success model for evaluating knowledge sharing. In International Workshop on Data Quality and Trust in Big Data (pp. 125-136). Springer, Cham.

Sharkey, U., Scott, M., \& Acton, T. (2010). The influence of quality on e-commerce success: an empirical application of the Delone and Mclean IS success model. International Journal of E-Business Research (IJEBR), 6(1), 68-84.

Shim, M., \& Jo, H. S. (2020). What quality factors matter in enhancing the perceived benefits of online health information sites? Application of the updated DeLone and McLean Information Systems Success Model. International Journal of Medical Informatics, 137, 104093.

Tam, C., \& Oliveira, T. (2017). Understanding mobile banking individual performance: The DeLone \& McLean model and the moderating effects of individual culture. Internet Research.

Tona, O., Carlsson, S., \& Eom, S. (2012). An empirical test of Delone and McLean's information system success model in a public organization.

Yakubu, M. N., \& Dasuki, S. (2018). Assessing eLearning systems success in Nigeria: An application of the DeLone and McLean information systems success model. Journal of Information Technology Education: Research, 17, 183-203. 